\title{
O BODEGÓN E A MESCLA: UMA SINTAXE TRANSATLÂNTICA
}

THE BODEGÓN AND THE MIXTURE: A TRANSATLANTIC SYNTAX

Julio Ortega

Brown University

Providence, Estados Unidos

Palavras-chave: Bodegón; poéticas transatlânticas; Barroco.

Palabras claves: Bodegón; poéticas transatlánticas; Barroco.

Keywords: Still life; transatlantic poetics; Baroque.

\section{Resumo}

Este trabalho pretende demonstrar que o gênero pictórico dos bodegones, característico do Barroco transatlântico, tem uma de suas origens na pobreza, nos restos da mesa espanhola do século XVII, sendo a outra origem a abundância americana, plena de frutas e lendas exóticas de fecundidade. Zurbarán foi o grande pintor de temas americanos, mas uma de suas obras mais famosas foi interpretada como representação alegórica da epifania da Virgem Maria. Este artículo pretende problematizar essa leitura a partir de um dado revelado por raios X: Zurbarán incluiu no quadro um prato de batata-doce, um tubérculo americano, que depois apagou e reproduziu em um quadro independente. O bodegón, portanto, é um gênero mais americano, menos místico e mais barroco.

\section{Resúmen}

Este estudio busca demostrar que el género pictórico de los bodegones, característico del Barroco trasatlántico, tiene uno de sus orígenes en la pobreza, en los restos de la mesa espańola de siglo XVII, siendo el otro origen la abundancia americana, plena de frutas y leyendas exóticas de fecundidad. Zurbarán fue el gran pintor de bodegones y usó temas americanos, pero una de sus obras más famosas ha sido interpretada como representación alegórica de la epifanía de la Virgen María. Este artículo busca problematizar esa lectura a partir de un dato revelado por los rayos X: Zurbarán incluyó en el cuadro un platillo de batatas, un tubér-

\begin{abstract}
This article argues that the pictoric genre still life, associated with the transatlantic Baroque, has one of its origins in Spanish poverty along the XVII Century and, on the other hand, in the abundance of the Indies. Francisco de Zurbarán was one of the best still life painters, and he used some themes from the New World. One of his most famous pieces, the still life with lemons and a cup of chocolate has been read lately as dedicated to the epiphany of Virgin Mary, transforming the cup of chocolate in a glass of water. This article discusses the dish of sweet potatoes that the painter took out of his painting, proving that still life is more from
\end{abstract}


culo americano, que luego quitó y pasó a un cuadro independiente. El bodegón, por lo tanto, es un género más americano, menos místico y más barroco. the Indies than from the mystic representation. It is, thus, mostly Baroque.

Embora o bodegón seja um gênero pictórico definido como característico do século XVII espanhol, tanto por seu estilo naturalista como pelo aproveitamento do claro-escuro e sua localização no Barroco, sua história cultural ainda não foi esclarecida e sua conceitualização tampouco proposta. Um de seus melhores historiadores, Peter Cheney, disse com razão: "A redescoberta da pintura de bodegones do século XVII na Espanha é um fenômeno do século XX". ${ }^{*}$ Nem mesmo a designação de "natureza-morta", consagrada pelos franceses, define o gênero do bodegón espanhol, que, diante de outras formulaçóes paralelas, como a pintura de flores, o vanitas e a marchetaria italiana, distingue-se pelo caráter empírico, decididamente barroco. Na Holanda, o still-leven ocorre por volta de 1650, enquanto na França a nature morte é definida em 1667 como "choses mortes et sans mouvement". A natureza-morta flamenga é mais decorativa, mais doméstica, e tende a um preciosismo meticuloso que é inevitável associar ao gosto da nova burguesia dos Países Baixos, recentemente enriquecida com a produção agrícola, as transaçóes bancárias e o comércio ultramarino. Snyders é considerado um dos pioneiros do gênero, entre 1610 e 1620 . O vanitas é, certamente, tremendista na Espanha (basta lembrar Valdés Leal), o que é ilustrado pela caveira, verdadeira lição espanhola de caducidade. No florilégio flamengo, a caveira será substituída por uma mosca decorativa.

A genealogia do bodegón espanhol está documentada, em primeiro lugar, por suas definições. Covarrubias não chega a registrar sua acepção pictórica, mas estabelece a origem de sua história material.

“BODEGÓN: o porão ou portal baixo, dentro do qual se encontra a bodega. Quem não tem quem lhe cozinhe a comida, nesse lugar a encontra preparada em conjunto com a bebida, de forma a chamá-la de bodega"**

Um dos seus primeiros registros, já problemático, aparece no Libro de Acuerdos del Concejo Madrileño (1498-1501). A prefeitura

*(CHENEY, Peter. Arte y Naturaleza, El Bodegón Español en el Siglo de Oro. Madri: Fundación Airtel, 1999: 27.)

* (Tesoro de la lengua castellana o española, 1611) 
controla o negócio de bodegones ("terão de ser feitos bodegones", dispóe), mas à frente deles, adverte, deverão estar novos taberneiros, que vendam somente vinho e não alojem "vagabundos que roubam e procedem mal". Em outro volume de Acuerdos (1502-1515), o conselho aumenta o preço do vinho vendido nos bodegones: "para nove maravedis o azumbre" (quase dois litros). Na Segunda Celestina (1534), Feliciano de Silva caracteriza bem a clientela quando Areúsa pergunta: "Onde arranjaste este capão, Centurio? Se... de algum bodegón, o cantarias?”. Centurio diz que gostaria de acompanhar Pandulfo a "um bodegón, onde bebêssemos para comemorar e falássemos em algaravia, ou melhor, em germania, como quem sabe bem disso". ${ }^{1 *} \mathrm{O}$ fato de o bodegón reivindicar sua própria liberdade verbal, rebaixada e de gente baixa, deve ter entusiasmado Mateo Alemán (Segunda parte de la vida de Guzmán de Alfarache, 1604), que o descreve com prazer: "Estes tais vão ao bodegón pela comida, à taberna pelo vinho e à praça com a sacola”. E também: "Olha que gentinha tão de bem!: beleguins, infames, traidores, ladróes, bêbados, desavergonhados. Falar em lacaio é falar em bodegón". Em Romances de germania de varios autores (anônimo de 1609) aparecem esses versos:

Diz-se do bodegón Registro

onde o dinheiro é registrado,

à taberna Alegria

que alegra o mais zangado.

"Lugar onde se preparam e fornecem refeiçôes simples". Esta é a definição mais comum, que os autores recompóem a seu modo, demonstrando que é um espaço marginal licencioso, mas também festivo e empírico, quase carnavalesco, onde a moral vigente é colocada em xeque. É revelador que este espaço mutante e fluído também convoque uma linguagem picaresca e quase obscena, animada por sua nudez retórica e sua crueza expressiva. Francisco López de Úbeda, em La picara Justina (1605), exacerba o jogo de palavras e sentencia:

É o dinheiro o plus ultra com que tudo cresce e progride. Nós, as damas, gostamos que visitantes acorram à nossa porta, que náo é bom bodegón onde não frequentam muitos. Amor, reduzido a dinheiro. [...] O Amor tem apenas dois casos [...] a saber: dativo e genitivo. O primeiro antes de se casar e o segundo para depois. Sou tão terrível

\footnotetext{
${ }^{1}$ Todos os fragmentos de obras literárias espanholas e hispano-americanas citadas no artigo foram traduzidos por mim. [N.T.]
} 
que até os nominativos me caíram bem! O dinheiro garante tudo ao galã casadouro.

Em La vida y hechos de Estebanillo González (anônimo, 1646), há uma descrição carnavalesca do espaço precário do bodegón:

montei um rancho, que nem bem era bodegón, nem bem hospedaria, mas um bodegonzinho táo humilde que a Guerra poderia dá-lo por Escondido ou perdoá-lo por pobre. Feito com duas águas e sem defesa para nenhuma; era todo aberto, e precisava de janelas; [...] não tinha porta nem fechadura nenhuma; suas mesas eram pedaços velhos de talhos de cortar carne, seus assentos de grandes e torneadas pedras... suas panelas e caçarolas de barro cozido e não vidrado, e sua baixela de massa do primeiro homem. Puseram-lhe o nome de Praça de Armas, por seu escasso abrigo e menor limpeza.

A alusão ao barro original faz do bodegón uma paródia do jardim primeiro; seu cardápio, por outro lado, carece de nomes: "A cada dia fazia um prato que nem eu sabia como poderia chamá-lo”.

Na segunda parte de Dom Quixote (1615), Sancho declara que espera fazer parte da série de pinturas que enfeitavam as paredes de bodegones e vendas com temas de comida e cenas clássicas. “ - Apostarei - disse Sancho - que em não muito tempo não haverá bodegón, venda nem estalagem ou barbearia onde não esteja pintada a história de nossas façanhas". Notavelmente, Dom Quixote retoma em sua resposta o drama da representaçáo pictórica e sua relação com a linguagem. Conta a fábula do pintor Orbaneja, que dizia pintar "o que saísse", e precisava esclarecer o que pintava: "Escrevia embaixo: 'Isso é um galo', para que não pensassem que era raposa”. O nome, não a imagem, anuncia o objeto. Mas se trata de um nome redundante, por literal: o pintor pinta mal e fala pior. Usa o nome não para aludir ao objeto, mas parafraseando-o, porque o objeto the escapa. Por isso, Dom Quixote passa a criticar o "pintor ou escritor" que publicou o novo e falso Quixote, "que pintou ou escreveu o que saísse”.

Os extremos da clientela são bem definidos em dois textos situados em polos opostos. Em El buscón (1626), Quevedo esclarece a índole de seus personagens, quando se autodefinem: "Somos susto dos banquetes, traça dos bodegones e convidados forçosamente”. Ao passo que Luzán, em La Poética (1737), adverte que "não há de entrar o poeta nos bodegones nem nas cavalariças." Quando o poeta assume o protocolo social de excluir-se dos espaços marginais, a pintura de bodegón já não é parte de sua genealogia, per- 
tence aos salōes e, logo, ao Museu. Por essa razão, o bodegón pictórico será condenado e destituído como arte popular por Antonio Palomino y Velasco (El parnaso español pintoresco laureado, 1724): "Herrera, el rubio. Pintou muita ninharia, como bodegones e figurinhas ao estilo de Callot". Novamente a disputa pela representação, desta vez entre a arte popular e a arte decorativa. Jacques Callot foi o gravurista francês que, além de batalhas e paisagens, gravou cenas truculentas e perturbadoras da guerra e do submundo. Sua arte gráfica foi muito difundida, influenciando Blake, Goya e Daumier.

Com efeito, faz sentido que este espaço marginal de pobreza seja o arquivo hispânico que designará as representaçóes dos frutos terrestres. A pobreza, crescente e aguda no século XVII espanhol, com certeza explica, como já proposto, novas formas narrativas, estilos e pontos de vista; inclusive a perspectiva anti-heroica e burlesca que vai impor a glosa e a paródia como variaçóes de contradição e rebaixamento. Quando o cronista andino Guamán Poma de Ayala imagina na sua Crónica (ca. 1615) um ordenamento real que dita: "Ordenamos que se coma em praça pública", certamente está fazendo coro com os freis tratadistas que tentavam combater a fome dos mais pobres.

Desde o final do século XVI, a pintura de flores e frutas adquire plenitude na Itália e em Flandres, e é evidente que seu modelo é o da representação popular da Abundância difundida pelo Humanismo e pela imprensa, e atualizada pelas riquezas de além-mar. A "Cesta de frutas" de Caravaggio é de aproximadamente 1596; e de meados do século são as "cenas de mercado" que testemunham a prosperidade da burguesia dos Países Baixos. Na Holanda, o "still-leven" $o u$ "modelo imóvel" ainda equivalia à pintura de frutas copiosas e quadros de banquetes. Na Espanha, por sua vez, o bodegón define melhor a pintura de frutas que, sob a perspectiva da pobreza e diante dela, representa a condição material dos alimentos como tributos da terra, virtude do tempo e posse humana. No entanto, só a partir de 1649 o bodegón adquire sua definição de gênero pictórico, quando o mestre Pacheco, em sua Arte de la pintura, declara seu valor. Mas a definiçấo do dicionário de Autoridades (1726) ainda remete à sua genealogia.

Bodegón. O porão ou alpendre onde se prepara e se cozinha a comida para as pessoas pobres e comuns: e por se instalar frequentemente às portas das tabernas e bodegas de lavradores, de modo que os que entram para beber tomem algo que lhes sirva de substância, pôde 
tomar o nome da palavra Bodega; embora Covarrubias diga que pode advir do italiano Budella, que são os intestinos do animal por semelhança fonética, e serem esses restos o que ali se vende mais regularmente para os pobres... Na pintura, assim são chamadas as telas nas quais estáo pintados pedaços de carne e de peixes, e comidas da classe baixa. ${ }^{2}$

Neste trabalho eu gostaria de propor que o bodegón espanhol, desde Juan Sánchez Cotán e Juan van de Hanan y León a Francisco de Zurbarán e Pedro de Comprobín, é um gênero plástico que surge como resposta cultural à crise material do início do século XVII. Responde à carência e à caducidade com as formas empíricas de uma linguagem do mundo natural, que recupera os frutos comuns e modestos como uma alegoria, tipicamente barroca, segundo a qual a imagem se reapropria de seu objeto para ocupar o espaço vazio ou carente com novas versões, terrestres e materiais. As formas esféricas, de polpa carnuda, declaram o estado maduro do fruto, o sabor e a textura de uma temporalidade encarnada. Essa reapropriação saborosa fora uma lição cultural forjada pela Crônica das Índias. Desdobrada na sintaxe barroca, capaz de incorporar, acrescentar e abrir espaço aos frutos ultramarinos, tanto na imagem da cesta com trançado clássico como na cozinha pública, essa representação dos alimentos postula que a mescla e o tempero dos bens deste mundo são a versão moderna da onda fertilizante; não só da natureza emblemática dos Humanistas, mas também da materialidade da cultura barroca. Minha hipótese é de que a soma e a mescla, essas duas formas culturais em que o Novo e o Velho mundo se encontram e se entrelaçam, são mecanismos de representação e apropriação subjacentes nas alegorias do bodegón. ${ }^{3}$

\footnotetext{
${ }^{2}$ Em uma edição mais moderna do Diccionario de la lengua castellana (RAE, 1899), lê-se: "Pintura ou quadro onde se representam coisas comestíveis." E no Modernísimo diccionario enciclopédico (México: Learte, 1951), lemos: "BODE$G O ́ N$.(Aumentativo de bodega). Lugar onde se cozinham e se dão de comer refeições simples. (2) Taberna. (3) Pintura onde se representam coisas comestíveis, jarras,vasilhas e utensílios vulgares.” Esta noção de vulgaridade só será corrigida no século seguinte. Mas sobre o valor desta arte temos um claro testemunho no testamento (1599) deixado por Juan Pantoja de la Cruz: “O senhor Agustín Álvarez, de Toledo, membro do Conselho de Índias de Sua Majestad, deve-me três quadros de pinturas grandes de três bodegones da Itália que fiz no ano de 92, que valem 300 reales cada: recebi 500 reales e tenho cartas de pagamento para esses a que me refiro: cobre-se dele."

${ }^{3}$ Em sua Natureza morta, Norbert Schneider propóe uma classificação ilustrada e didática do gênero, que inclui seçôes dedicadas às "cozinhas", "cenas de caça", "os cinco sentidos", "vanitas", "sobremesas e doces", "mesas postas", "cestas com
} 
* (BRYSON, Norman. Chardin and the text of Still Life. Critical Inquiry. The University of Chicago Press, v.15, n.2, inverno de 1989: 227.)

* (BAXANDALL, Michael. Patterns of intention. On the historical explanation of pictures. New Haven: Yale University Press. p. 70-114.)
Diversas vezes se advertiu sobre a necessidade de uma teoria que conceitualizasse o gênero da natureza-morta. Norman Bryson, em seu trabalho sobre Chardin, o mais importante artista francês do gênero - embora pertença ao século XVIII -, defende a hipótese de que a natureza-morta "é o gênero mais distante da linguagem e, por isso, o mais difícil de alcançar com o discurso".* E, ainda que proponha que a ausência de sujeito nos quadros de Chardin pode ajudar a entender melhor Sánchez Cotán e Zurbarán, é evidente que Chardin esteve mais preocupado em desenvolver o ilusionismo de uma vertente francesa do gênero. ${ }^{4}$ Baxandall, por sua vez, discute esses dramas da representação baseando-se nas ideias de Locke sobre a percepção.* Contudo, no bodegón espanhol e em suas versões americanas, o sujeito do bodegón está mais presente por não estar representado. Vemos a cena do olhar barroco, a intensidade da representaçáo, como a atividade do sujeito que nos adiciona ao relato de sua visão. Não é o ditame de um olhar normativo e naturalista o que nos captura com sua suposta transparência; mas tampouco se trata do olhar que sublima o mundo que vê, declarando sua ilusão. Ou seja, a comunicação que se estabelece diante do bodegón é um drama do diálogo e do sentido, alegorizado nessa figura verbal, nessa ação comunicativa. Os alimentos estão pintados da parte do espectador, cuja função de olhar vai articulando uma visão. Do outro lado está o artista, pintando o que vemos. Por essa razão, o sentido é uma posse de quem olha e um tributo de quem representa: dar e receber é a comunicação que constrói o significado dos objetos, o valor dos alimentos, o dom do que está vivo.

Se o empirismo barroco supóe o decurso temporal dos bens terrestres, o seu naturalismo patente não é uma estilização, mas um desdobramento que enche de presença o olhar do sujeito, não menos barroco. Nesse diálogo, a imagem acumulativamente elaborada transforma-se em emblema e este, por sua vez, projeta-se como alegoria, elogio e tributo do vazio preenchido náo por horror, e sim por dádiva. O bodegón, por esse motivo, parece assumir a lição de coisas da Crônica das Índias: o que vemos é o que não

frutos", "flores", "cenas religiosas com flores e frutos", "museus, gabinetes de curiosidades e de história natural", "instrumentos de música", "armas", "livros" e "cenas de bosques”, embora dedique pouca atençáo à parte espanhola.

${ }^{4}$ Explica Bryson: "Hiper-real, o trompe l'oeil imita e parodia o sentido do real, de maneira a lançar dúvidas sobre o lugar do sujeito no mundo e se o sujeito realmente tem um lugar no mundo." E anota que os "aspectos vertiginosos" da naturezamorta foram explorados por Jean Baudrillard em seu ensaio sobre o trompe-l'oeil. 
temos e só podemos ter na arte da natureza e no artifício da pintura. Os frutos do bodegón espanhol, dir-se-ia, representam a veemência de um desejo: sua presença, por isso, é sensorial e ao mesmo tempo epifânica. O paradoxo do mundo é uma lição moderna: a figura como projeção supóe que o vemos porque nos escapa. É um objeto de transposição e equivalência, o que corresponderia a um conceito. Mostrar começa por revelar o contrário: o mundo é mais pleno em sua ausência. Daí que o bodegón seja um relato sobre o lugar do sujeito da modernidade problemática. Já não se trata do sujeito da abundância que Luis de Granada consagrara como saturado pelo prazer de um mundo que o saciava de tal maneira que Deus havia previsto inclusive distraí-lo do fastio. Agora é o sujeito da carência, que reconhece o valor e a força dos nomes nas coisas representadas pela conectividade de uma sintaxe capaz de restituir o mundo extraviado. É exatamente o que faz Góngora com a linguagem poética: tece uma hipérbole extremada, cuja imagem verbal seja capaz de renomear ("Não é surdo o mar, a erudição engana”). É o que faz também o Inca Garsilaso de la Vega quando volta a erguer a fortaleza de pedra que havia sido derrubada, como se reordenasse as sílabas de um discurso rompido que poderemos ler graças à sintaxe que triunfa sobre a violência da história. $\mathrm{O}$ sujeito não é mais ibérico ou incaico: é um ator transatlântico, convocado pela sintaxe cultural da mescla, na cena da página, nos labores da leitura, na nova geotextualidade do espanhol moderno.

Lope de Vega vê isto muito bem quando enumera, por volta de 1620: "Um bodegón pintado e quatro mapas".* O bodegón e os mapas: o diálogo de duas representaçóes do mundo.

A pergunta que paira sobre o bodegón espanhol tem sido, reiteradamente, uma dúvida lançada sobre a suficiência de sua representação. Se ele é "engano" barroco, não se deve à acuidade de sua ilusão, mas ao engenho conceitual de sua sintaxe: os alimentos pertencem ao tempo e remetem ao ritual de seu tributo; inclusive, podem evocar o transe embevecido de um alimento mais interior. Mais do que ao gênero, o bodegón espanhol corresponde ao engenho. Ou seja, à sua fecunda e simultaneamente contida diferença. Sánchez Cotán, por exemplo, compraz-se na riqueza do detalhe em um espaço quase escultórico, que dramatiza a forma natural diante do espaço construído entre vazios. Chama a atenção que tenha pintado dois grandes quadros exatamente iguais, com uma diferença no segundo: o assombro de um fruto americano. Trata-
* (VEGA, Lope de. Querer la propia desdicha, Obras. RAE, 1916-1930, t XIII.) 
* (BATTISTI, Eugenio. Renacimiento y Barroco. Madri: Cátedra, 1990: 205.)

se do challote $^{5}$ (que ainda é chamado assim na América Central), nome náhuatl de uma abóbora delicada, de forma irregular, esverdeada. O primeiro quadro parece representar a cozinha antes da América; o segundo, a mesma cozinha depois da América. Tratase da sintaxe barroca, que entre um e outro mundo faz da pintura o cenário de um prodígio. Sabe-se que o Barroco se enriquece e se exalta com o gabinete americano: seria inconcebível sem a prata, os pássaros coloridos, o ouro, o chocolate, o tabaco e o abacaxi... Sem falar no jardim de plantas americanas ou na real botica.

Considerado gênero menor, o bodegón carece do artifício que, no início do século XVIII, o francês Félibian postula para a arte maior: aquela que utiliza os efeitos da natureza, que são grandes, extraordinários e parecem verdadeiros; uma arte que se deve ao "gênio", produto da natureza mas também da cultura, das normas e da reflexão. Em contrapartida, a paisagem barroca, como propôs Eugenio Battisti baseando-se em Curtius, pode ser definida como "uma mescla entre o locus amoenus e o lugar selvagem".* Isto é, entre a Antiguidade e o Moderno. Desde Colombo até o Inca Garcilaso, o discurso da abundância americano transforma o locus amoenus em locus copioso, o lugar harmonioso na abundância do intercâmbio e do comércio. Isidoro de Sevilla já tinha observado que havia boa lenha no Paraíso.

Os signos americanos que inquietam a representação da despensa espanhola têm no chocolate sua principal matéria aleatória: seu repertório vai das sementes do cacau até o preparo e a forma de servi-lo, passando pelas vasilhas, vários delas procedentes da América, as xícaras de prata peruana e as chocolateiras inventadas na Itália. O chocolate é um produto ao mesmo tempo exótico (remoto) e doméstico (familiar), ainda que sua fama seja toda uma farmacopeia. Uma matéria, além de tudo, eminentemente barroca, que está presente inclusive no severo altar caseiro, e que reaparecerá nas variaçóes francesas, mexicanas e norte-americanas do "realismo mágico". Uma receita barroca de preparado de chocolate nos parece hoje um prodígio da mescla. É nesta convicção moderna de que o conhecimento do novo é o alimento do saber que se baseia, na minha avaliação, a tese cultural elaborada pelo Inca Garcilaso de la Vega a partir da sua visão sobre a abundância produzida pela mescla transatlântica. A história cultural do

\footnotetext{
${ }^{5}$ Chuchu. [N.T.]
} 
novo é sua fecundidade, isto é, seu futuro. Assim como a natureza não terminou de se fazer, porque continua atualizando o prodígio de seus bens, a cultura se faz nesta sintaxe incorporadora, que é a própria linguagem do mundo como uno e pleno. E o homem, filho da mescla das naçóes próximas e remotas, nasce e renasce para a nação do novo, a da mestiçagem, que é o futuro ao qual Garcilaso se reporta, inventando, na Historia, um irmão leitor de além-mar, um homem vindouro com quem estabelecer diálogo. Que o modelo natural (a abundância fecunda) tenha se transformado em um paradigma cultural (a mestiçagem transatlântica) e seja, finalmente, uma hipótese política (a modernidade da mescla) ilustra a nobreza humanista desse filólogo neoplatônico, alimentada tanto pelo quéchua aglutinador como pela promessa da Cidade barroca, feita de vários mundos.

O governador holandês do Brasil - cuja pródiga extensão esteve parcialmente ocupada, entre 1630 e 1654, pela colonização holandesa - decidiu contratar uma série de cientistas e artistas para documentar a abundância da paisagem local. Entre eles, dois pintores de alto nível: Frans Post e Albert Eckhout. As primeiras naturezas-mortas americanas se chamaram "Colheita tropical”, e mostram, sob um céu cósmico, a voluta e a textura, a dobra e a cor carnosa da abóbora e do nabo, da goiaba e do abacaxi. Mas logo o formato botânico, de lâminas taxonômicas, impôs-se como ciência natural, apesar de os artistas, gravadores e impressores não terem deixado de recuperar as cores da selva no gabinete e no mercado. Um dos melhores foi o pintor huguenote que Francis Drake levou ao Caribe. As lâminas que pintou transmitem uma gozosa curiosidade. E são ricas em detalhes, com um empenho naturalista de botânico aficionado, preciso e racional. Embora não deixe de desenhar o diabo fugindo da aldeia diante da figura decididamente moderna de Drake. ${ }^{6}$

Resta-nos ainda explorar o impacto do desenho botânico e da imprensa na difusão da abundância americana na Espanha e na Europa barroca e rococó. Desde as pinturas verbais de Fernández de Oviedo até os frutos gigantescos produzidos pelas sementes espanholas em terras americanas, promovidas pelo Inca Garcilaso, esse cenário de intercâmbios, recodificações e fecundas apropriaçôes constrói o imaginário transatlântico, antes de a paisagem ser

\footnotetext{
${ }^{6} \mathrm{O}$ manuscrito Drake está na Morgan Library (Nova York). Uma consideração sobre os desenhos integra meu livro Transatlantics Translations.
} 
ocupada pela iconografia das "Índias galantes" e a nova burguesia colonial. Ainda nos falta conceitualizar a gravitação dos repertórios científicos dos viajantes, botânicos e linguistas que, no século XVIII e início do XIX, alçam a iconografia americana à condiçâo não apenas de ciência ilustrada e testemunho documentado, mas de curiosidade pitoresca. Entre Mutis e Humboldt, esse repertório é um capítulo à parte da representação da América, não mais na natureza-morta, mas na taxonomia e na medicina. Quando Mutis enviou ao famoso Linneo a rara flor da quina, o sábio a observou imperturbável e encontrou um lugar para ela em seu mapa do universo: coube sem problema, prevista pelo Catálogo. ${ }^{7}$ Porém, ainda na última década do século XIX, quando o grande pintor porto-riquenho Francisco de Oller resolveu deixar os salóes de Paris e voltar para seu país, foi o formato do bodegón que decidiu atualizar para promover, como se estivesse recomeçando, a reafirmação universal de sua ilha, graças às bananas e às graviolas.

O bodegón mais famoso é "Limones, naranjas y una rosa" (1633), de Francisco de Zurbarán (Sevilha, 1620-1649), que se encontra na Norton Simon Foundation, em Pasadena, Califórnia. Só foi mencionado em 1924 e exibido apenas em 1930. Já em 1924, o crítico que informou sobre o quadro, August L. Mayer, se perguntava se a xícara seria de chocolate. "Esta natureza-morta é grandiosa em sua simplicidade e na elegância de seu desenho. É tão luminosa quanto uma obra de Cézanne...”. Dois anos depois, Mayer volta a falar do bodegón, e desta vez convicto de que a xícara é de chocolate, porque é idêntica à que aparece no quadro "La educación de la Virgen”. Outros críticos e historiadores viram a obra como uma celebração da natureza contemplada em seu esplendor; e o copo metálico, disseram, é de chocolate. Julian Gállego (desde 1962) sugeriu tratar-se de um tributo à epifania da Virgem Maria. E, para que sua interpretação fosse consistente, decidiu que o copo era de água:

\footnotetext{
${ }^{7} \mathrm{O}$ estudo iconográfico da zona de interação transatlântica é uma área ainda a ser documentada, categorizada e teorizada. Um trabalho que abre caminho e demonstra as possibilidades é o de Mary Louise Pratt, Imperial Eyes: Travel Writting and Transculturation (Londres: Routlege, 1992), publicado no Brasil como Os olhos do império: relatos de viagem e transculturaçâo (Bauru, EDUSC, 1999). Também são de grande interesse os estudos de Mercedes López Baralt, Juan Ossio, Luis Millones e Raquel Chang-Rodríguez.
} 
Eu me atrevo a interpretar o referido bodegón - escreve - como uma homenagem à Virgem: a travessa de cidras, fruta até hoje utilizada na Itália na paraliturgia pascoal; a cesta de laranja e flores de laranjeira - virgindade e fecundidade; a xícara de água - pureza fértil - posta em um pires prateado com uma rosa - amor divino...*

Temos que conceder-lhe o copo de água, que a maioria preferiu ao de chocolate. William B. Jordan (1985) adverte que, embora a visão do quadro como "expressão simbólica da devoção religiosa" não possa ser desaprovada, sua importância "pode ter sido exagerada”**

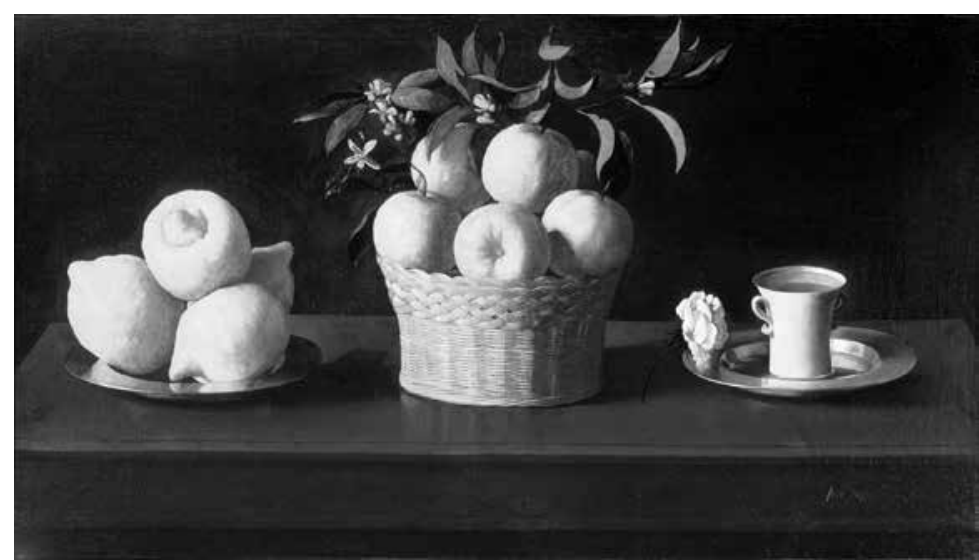

Figura 1. Francisco de Zurbarán. Bodegón con canasta de naranjas, 1633, Óleo, $62.2 \times 109.5 \mathrm{~cm}$. The Norton Simon Museum Foundation, Pasadena, Califórnia.

Mesmo baseada na conhecida observação de que, na pintura barroca, os objetos tendem a representar um motivo religioso ou moral, esta leitura simbólica acaba deixando de lado a presença sensível da natureza e transformando o quadro em uma mecânica analógica excessivamente próxima da pintura didática, segundo a qual as frutas já não são suficientes por si mesmas e se tornam mediaçóes de outro discurso, unívoco. Jordan observou que essa leitura carece de documentação e que tampouco existem provas de que o público de seu tempo reconheceria o simbolismo intencional. Ainda mais decisivo me parece o fato de que o reducionismo alegórico contradiz o naturalismo eloquente do artista. Seus objetos e personagens têm uma veemência concentrada que parece exceder sua mundanidade: mas é a intensidade da presença que confere ao quadro sua projeção cênica.
* (GÁlLEGO, Julián. Visión y símbolos en la pintura española del Siglo de Oro. Madri: Cátedra, 1996: 202.)

* (JORDAN, William B. Spanish Still Life in the Golden Age, 1600-1650. Kimbell Art Museum, Forth Worth, 1985.) 
Gállego, como tantos críticos, não encontra espaço para o incongruente objeto americano, e opta por esvaziar a xícara histórica para enchê-la de água epifânica. Perde assim seu caráter de elegia do mundo, o Velho e o Novo somados pelo olhar celebratório. Pelo mesmo motivo, não surpreende que outros leitores tenham escolhido ver nas três unidades do quadro nada menos do que a própria Trindade. Como diz Cherry, transformaram a mesa da cozinha em um altar.

Não obstante, mesmo que se aceitasse que as três unidades deste bodegón (cuja poderosa referência ao ecónomos doméstico é própria do empirismo barroco) são uma oferenda à Virgem Maria, não é sensato desconsiderar a poderosa representação de vida material que há em seus frutos, cuja pele e polpa, luz e cor, sugerem que foram feitos para ser tocados e experimentados. Mesmo que as laranjas e as flores de laranjeira tivessem que corresponder à Virgem, a xícara de chocolate sobre o pires de prata corresponderia a uma mãe recente. Afinal de contas, o chocolate americano tinha a fama de reconstituinte de parturientes. ${ }^{8}$

Porém, a esplêndida peça de Zurbarán escondia outra revelação. Os raios $\mathrm{X}$ descobriram que, entre os limóes e a cesta, o artista havia pintado um prato de "batatas-doces confeitadas", que depois foi apagado pelo artista.

\footnotetext{
${ }^{8}$ Em seu comentário sobre este bodegón, Jonhatan Brown, procurando equilibrar a discussão, adverte: "É difícil para nós aceitar o magnífico still life de Zurbarán como uma obra artística trivial. De fato, atualmente é reconhecida como uma de suas obras-primas. Até mesmo para um apreciador casual, ela gera um impacto completamente desproporcional com o seu despretensioso tema. Zurbarán aparentemente elevou objetos humildes ao mais alto plano de realidade, e esta impressão fez com que alguns escritores interpretassem o fruto e a xícara de água como símbolos religiosos ou oferendas votivas. $\mathrm{Na}$ falta de qualquer outra intenção simbólica, talvez seja melhor ver o trabalho por meio do olhar de Pacheco: como uma peça de exposição de virtuosidade artística que pintores figurativos ocasionalmente realizam por divertimento. Isso não quer dizer que Zurbarán não o levou a sério. Cada aspecto da obra foi calculado para produzir o efeito da natureza elevada por artifício ao seu poder mais alto." (1991).
} 


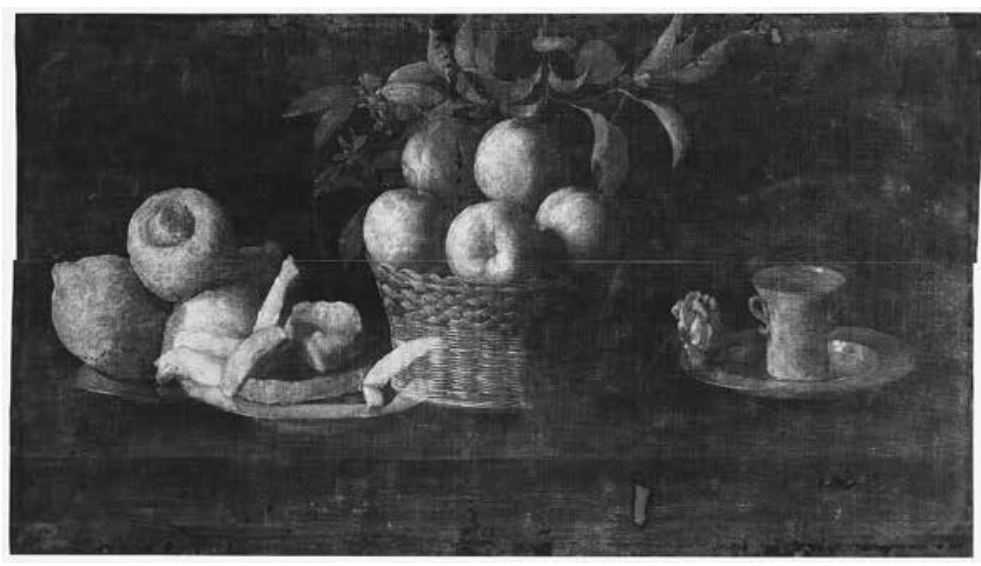

Figura 2. Radiografia de Bodegón con canasta de naranjas (e um pratinho de batatas-doces ou camotes confeitados). O motivo foi recuperado separadamente por Zurbarán (Batatas confitadas en un platillo de plata, ca. 1633. Óleo, 28.5 x $39 \mathrm{~cm}$. Espanha, coleção privada).

O tubérculo americano confere ao quadro uma referência mais doméstica e cotidiana. Trata-se de um doce ou sobremesa polpuda e de formato menos gracioso, porém de matéria mais imediata, que no lugar da casca madura tem uma cobertura de açúcar. É, assim, uma presença do sabor: fala diretamente aos sentidos. O açúcar, um toque de luxo sobre a simplicidade americana da batata-doce (camote, em outros países do continente), era um produto caro, geralmente importado de Portugal. De modo que, na sintaxe da composição do bodegón, onde se somam matérias e sabores do Velho e do Novo Mundo (e de outros mundos também), os bens americanos (chocolate, batata-doce) ampliam a cena para a história, mais empírica e mundana, de seus intercâmbios e reinscriçóes. Mesmo seu desaparecimento (a batata da mão do pintor, o chocolate do olhar de alguns críticos) faz parte da cena barroca, de sua estranheza e ambivalência. Nesta sintaxe, esses produtos estão, algumas vezes, tácitos; em outras, subitamente presentes, como o americano chuchu que aparece em um dos dois bodegones idênticos de Sánchez Cotán; como signos do terrestre - ligeiramente incongruentes, porém verazes -, são uma intrusão no espelho do espectador.

O gênero da "natureza-morta" espanhola ganha em mediaçóes vencidas e em intimidades plenas graças ao caráter imediato desses sabores e formas americanas, que transbordam tanto a geometria do espaço como a circularidade do tempo; e fazem isso no cenário barroco, onde ampliam a sintaxe de uma hipérbole celebratória. São 
fruta e fruto, posse fecunda do sabor que humaniza o mundo. Até o doce apagado e o chocolate invisível declaram a nova proximidade do Novo Mundo na redefiniçáo europeia de provar e saber, do sabor e do empírico. "Eu comi da fruta", ou "eu provei do fruto", os cronistas nos dizem repetidas vezes, declarando a epifania do novo.

Fernandez de Oviedo, que não se privou de nada, tinha jogado na cara de Pedro Mártir que ele falava do abacaxi sem tê-lo conhecido. Eu sim o provei, reafirma, com conhecimento de causa. Pedro Mártir esperava a nau que trazia os abacaxis prometidos, mas no final da travessia eles chegavam estragados, para seu desconsolo. Ele deve ter sentido, apesar de todo o seu latim, que uma sílaba da linguagem do Novo Mundo (mundo significa limpo: linguagem outra vez prístina, do primeiro dia) lhe escapava. Até mesmo com sua ausência, o abacaxi americano já representava o engenho da própria Natureza. Não obstante, um esplendoroso abacaxi chegou à mesa de Felipe II. $\mathrm{O}$ monarca o viu em seu prato, contemplou-o em silêncio, e decidiu não experimentá-lo. Sua autoridade residia no náo saber, no monólogo de uma era anterior à sintaxe transatlântica.

Tradução: Diogo de Hollanda Cavalcanti Doutorando em Letras Neolatinas. UFRJ

Julio Ortega é Catedrático de Literatura Hispano-americana na Universidade de Brown. Estudou Literatura na Universidade Católica de Lima. Foi professor visitante nas Universidades de Pittsburgh, Yale, Harvard e Porto Rico. Também exerceu docência nas Universidades de Salamanca, Granada, Las Palmas, Universidade Católica do Chile, Universidade Simón Bolívar e Universidade de Londres. Ocupou a cátedra Simón Bolívar da Universidade de Cambridge e também foi catedrático em Literatura Latino-americana na Universidade do Texas e na Universidade de Brandeis (EUA). Doutor Honoris Causa pela Universidade del Santa (Peru), Universidade Los Angeles (Peru) e Universidade Americana da Nicarágua. Atualmente dirige o Projeto Transatlântico na Universidade de Brown. Tradutor e editor, dirige as coleçóes "Aula Atlántica", do Fondo de Cultura Económica, "Entre-Mares", da Editorial Veracruzana, y "Nuevos Hispanismos", da Iberoamericana-Vervuert. Autor, entre outros titulos, de Transatlantic Translations (2006); Rubén Dario y la lectura mutua (2004); Caja de herramientas. Prácticas culturales para el nuevo siglo chileno (2000); El principio radical de lo nuevo (1997); Retrato de Carlos Fuentes (1995); Arte de innovar (1994); El discurso de la abundancia (1992); Una poética del cambio (1992); Reapropiaciones: Cultura y literatura en Puerto Rico (1991); Gabriel García Márquez and the Powers of Fiction (1988); Critica de la Identidad (1988); Cultura y modernidad en la Lima del 900 (1987). E-mail: <julio-ortega@brown.edu>. 